\title{
First occurrence of Dolicholagus longirostris larvae (Maul 1948) (Osmeriformes, Bathylagidae) near the mouth of the Amazon River
}

Paula Nepomuceno Campos ${ }^{1}$, Rosildo Santos Paiva ${ }^{2}$, Ana Cristina Teixeira Bonecker ${ }^{3}$, Nuno Filipe Alves Correia de Melo ${ }^{4,5}$, Glauber David Almeida Palheta,

Cristiane Teixeira Contente ${ }^{4} \&$ Caio Aguiar Rodrigues Ramos ${ }^{4}$

Biota Neotropica v7 (n1)

http://www.biotaneotropica.org.br/v7n1/pt/abstract?short-communication+bn01007012007

Data Received 28/09/05

Revised 20/09/06

Accepted 01/01/07

${ }^{1}$ Lab. de Botânica, CCB, UFPA, Campus Universitário Guamá, R. Augusto Corrêa, 01, Guamá,

CEP66075-110,Belém, PA, Brasil,e-mail: polinhacampos@yahoo.com.br

${ }^{2}$ Curso de Pós-graduação em Ciência Animal, Centro Agropecuário,UFPA, e-mail: rpaiva@ufpa.br

${ }^{3}$ Laboratório Integrado de Zooplâncton e Ictioplâncton, Departamento de Zoologia,

Instituto de Biologia, UFRJ, e-mail: ana@biologia.ufrj.br

${ }^{4}$ Laboratório de Ecologia Aquática e Aqüicultura Tropical, ISARH, UFRA

${ }^{5}$ Autor para correspondência: Nuno Melo,e-mail: nuno.melo@ufra.edu.br

Abstract

Campos, P.N., Paiva, R.S., Bonecker, A.C.T., Melo, N.F.A.C., Palheta, G.D.A., Contente, C.T. \& Ramos, C.A.R. First occurrence of Dolicholagus longirostris larvae (Maul 1948) (Osmeriformes, Bathylagidae) near the mouth of the Amazon River. Biota Neotrop. Jan/Apr 2007 vol. 7, no. 1 http://www.biotaneotropica.org.br/v7n1/pt/abstract?short-communication+bn01007012007 ISSN 1676-0603

The family Bathylagidae contains eight genera and 22 species, of which only five occur in the Southwest Atlantic. Until recently, only adult specimens of the bathylaginin Melanolagus bericoides had been recorded off southern Brazil, between the Santa Marta Cape and Rio Grande ( $31^{\circ} \mathrm{S}$ and $49^{\circ} \mathrm{W}$ ). The present work reports the first occurrence of Dolicholagus longirostris larvae on the northern Brazilian coast, expanding its distribution in the Southwest Atlantic. The two specimens found were collected near the mouth of the Amazon River $\left(02^{\circ} 00^{\prime} 19^{\prime \prime} \mathrm{N}, 47^{\circ} 03^{\prime} 30^{\prime \prime} \mathrm{W}\right.$, and $\left.00^{\circ} 49^{\prime} 06^{\prime \prime} \mathrm{N}, 46^{\circ} 25^{\prime} 09^{\prime \prime} \mathrm{W}\right)$.

Keywords: longsnout blacksmelt, Bathylagidae, fish larvae, distribution, north Brazilian coast

Resumo

Campos, P.N., Paiva, R.S., Bonecker, A.C.T., Melo, N.F.A.C., Palheta, G.D.A., Contente, C.T. \& Ramos, C.A.R. Primeira ocorrência de larvas de Dolicholagus longirostris (Maul 1948) (Osmeriformes, Bathylagidae) próximas à foz do rio Amazonas. Biota Neotrop. Jan/Apr 2007 vol. 7, no. 1 http://www.biotaneotropica.org.br/v7n1/pt/abstract?short-communication+bn01007012007 ISSN 1676-0603

A família Bathylagidae apresenta oito gêneros e 22 espécies, sendo que apenas cinco destas espécies ocorrem no Atlântico Sudoeste. No sul do Brasil já havia sido registrada a ocorrência de exemplares adultos de Melanolagus bericoides entre o Cabo de Santa Marta e Rio Grande $\left(31^{\circ} \mathrm{S} \mathrm{e} 49^{\circ} \mathrm{W}\right)$. Este trabalho registra a primeira ocorrência de larvas de Dolicholagus longirostris na costa norte brasileira, ampliando sua distribuição no Atlântico Sudoeste. Os dois exemplares encontrados foram coletados na foz do Rio Amazonas (02 $00^{\prime} 19^{\prime \prime}$ N, $47^{\circ} 03^{\prime} 30^{\prime \prime}$ W, e $00^{\circ}$ 49' 06” N, 46 25' 09”' W).

Palavras-chave: "longsnout blacksmelt", Bathylagidae, larva de peixe, distribuição, costa norte brasileira. 


\section{Introduction}

The Bathylagidae are marine fishes with meso-bathypelagic habits. They can be found at depths of over $1000 \mathrm{~m}$, where they feed mainly on planktonic organisms (Kenaley \& Hamilton Jr. 2006). They occur in the Atlantic, Pacific, and Indian oceans, and have no commercial importance (Carpenter 2002).

According to Frose \& Pauli (2006), this family includes eight genera and 22 species, of which only five species occur in the southwest Atlantic: Bathylagus antarcticus Günther 1878, B. gracilis Lönnberg 1905, B. greyae Cohen 1958, Dolicholagus longirostris (Maul 1948), and Melanolagus bericoides (Borodin 1929). Off southern Brazil, adult specimens of Melanolagus bericoides $(193 \mathrm{~mm})$ have been recorded between the Santa Marta Cape and Rio Grande $\left(31^{\circ} \mathrm{S}\right.$ and $49^{\circ} \mathrm{W}$ ) (Figueiredo et al. 2002, Menezes et al. 2003).

The occurrence of the longsnout blacksmelt $D$. longirostris off the northern Brazilian coast is reported for the first time herein, which expands its distribution in the Atlantic. Some morphometric characters are also described.

\section{Material and Methods}

The specimens included in this study were collected during field activities of the Brazilian research program REVIZEE (a Portuguese acronym for Assessment of the Sustainable Yield of the Living Resources in the Exclusive Economic Zone). The samples were collected during two oceanographic campaigns off the northern Brazilian coast (Figure 1). The first expedition (PROSPEC XXIII) covered an area off the mouth of the Amazon River in the State of Pará ( $02^{\circ} 37^{\prime} 30^{\prime \prime} \mathrm{N}$, $47^{\circ} 49^{\prime} 20^{\prime \prime} \mathrm{W}$, and $02^{\circ} 45^{\prime} 89^{\prime \prime} \mathrm{N}, 48^{\circ} 02^{\prime} 58^{\prime \prime} \mathrm{W}$ ), during the early flooding period of the Amazon River (December 2001). The second expedition (North IV Operation) covered an area off the coast of Pará $\left(0^{\circ} 02^{\prime} 2^{\prime \prime} \mathrm{N}, 46^{\circ} 05^{\prime} 02^{\prime}\right.$ ' W, and $4^{\circ} 28^{\prime} 53^{\prime \prime} \mathrm{N}, 48^{\circ} 52^{\prime} 95^{\prime}$ ' W)

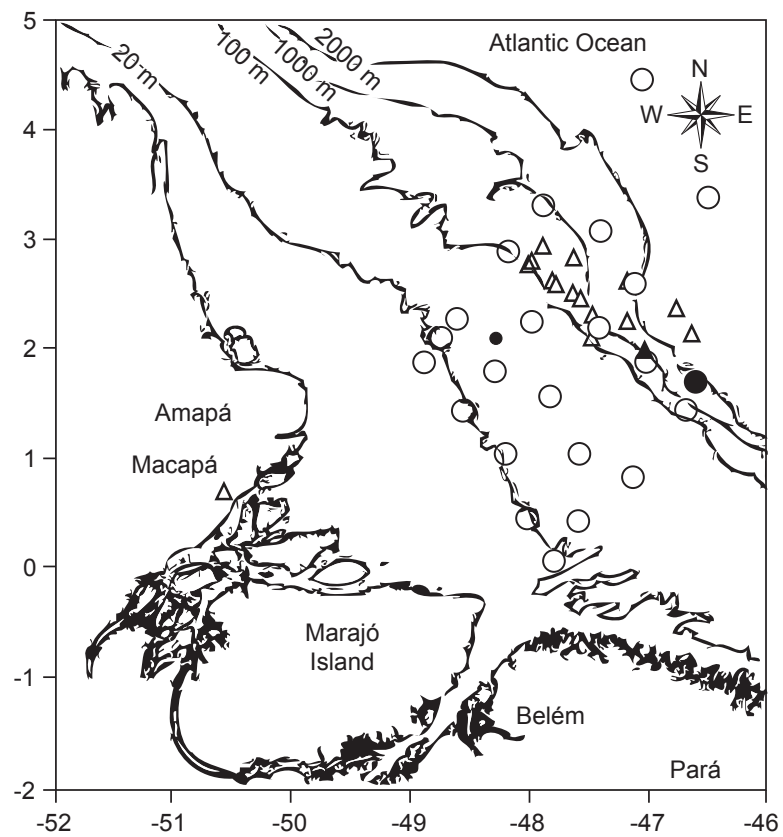

Figure 1. Study area with stations sampled during the North IV Op. (O) and PROSPEC XXII $(\Delta)$. The black circle and triangle indicate the stations where Dolicholagus longirostris was collected in both campaigns.

Figura 1. Área de estudo com as estações amostradas durante a Op. Norte IV $(\mathrm{O})$ e PROSPEC XXII $(\Delta)$. O circulo preto e o triangulo indicam onde Dolicholagus longirostris foi coletado nas duas campanhas. in July and August 2001, during the transition between the highest and lowest discharge of the river.

Samples were taken by means of a bongo net $250 \mathrm{~cm}$ in length, with a mouth $60 \mathrm{~cm}$ in diameter and mesh aperture sizes of 300 and $500 \mu \mathrm{m}$. The collections were made in oblique tows, from a depth of $200 \mathrm{~m}$ to the surface. The samples were immediately preserved in a borax-buffered solution of $4 \%$ formalin.

Fish larvae were sorted, measured and identified by means of a stereoscopic microscope in the "Laboratório de Botânica da Universidade Federal do Pará", and were then preserved in ethanol. The characters used to identify $D$. longirostris larvae were based on the description of Kenaley \& Hamilton Jr. (2006), and included pigmentation pattern, intestine length, and type of eyes. All measurements were taken with a millimeter ruler (precision $0.1 \mathrm{~mm}$ ).

The D. longirostris voucher specimens are deposited in the larval fish collection of the "Laboratório Integrado de Zooplâncton e Ictioplâncton da Universidade Federal do Rio de Janeiro (DZUFRJ)". Figures are based on the original collected material.

\section{Results and Discussion}

The northern Brazilian coast supports a highly diverse marine and estuarine ichthyofauna (Camargo \& Isaac 2003). The two major factors acting in the region are the Amazon River discharge, and the North Brazil Current (NBC), as well as the input of macronutrients derived from local estuaries. These factors affect the distribution of ichthyoplankton off the northern Brazilian coast (Paiva 2001).

The samples taken off the mouth of the Amazon River resulted in the collection of 847 eggs and 654 fish larvae, representing 11 orders and 28 families: Chlopsidae, Muraenidae, Ophichthidae, Congridae, Nettastomatidae, Engraulidae, Clupeidae, Bathylagidae, Phosichthyidae, Paralepididae, Myctophidae, Bregmacerotidae, Hemiramphidae, Holocentridae, Serranidae, Priacanthidae, Carangidae, Bramidae, Lutjanidae, Labridae, Scaridae, Chiasmodontidae, Gobiidae, Acanthuridae, Scombridae, Bothidae, Paralichthidae and Pleuronectidae.

Two larvae of Bathylagidae were found, and were identified as $D$. longirostris. Both of them were in the pre-flexion stage, with standard lengths (SL) of 7.16 and $8.51 \mathrm{~mm}$. The intestine was long, measuring 6.48 and $7.63 \mathrm{~mm}$ respectively, which corresponded to about $90 \%$ of the total body length. The larvae had pedunculated eyes and four pigmented areas on the ventral head, between the operculum and the mandible (Figure 2). Additional pigmented areas were aligned on the myomeres along the body, and there were small melanophores on the posterior part of the gut, in the ventral region (Figure 3).

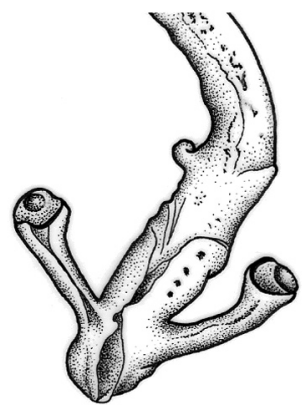

Figure 2. Detail of the pedunculated eye and pigmentation pattern on the ventral region of the head of a larva of Dolicholagus longirostris (DZUFRJ 11457; $7.16 \mathrm{~mm} \mathrm{SL).}$

Figura 2. Detalhe do olho pedunculado e padrão de pigmentação na região ventral da cabeça de uma larva de Dolicholagus longirostris (DZUFRJ $11457 ; 7.16 \mathrm{~mm} \mathrm{SL})$. 


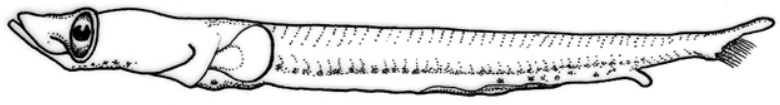

Figure 3. Pre-flexion larva of Dolicholagus longirostris (DZUFRJ 11456; $8.51 \mathrm{~mm} \mathrm{SL}$ ).

Figura 3. Larva em pré-flexão de Dolicholagus longirostris (DZUFRJ 11456; $8.51 \mathrm{~mm} \mathrm{~S}$

According to Ahlstrom et al. (1984), the main useful characteristics to identify Bathylagidae larvae are their sessile or pedunculated eyes, and the pattern of the body melanophores (number and sequence of formation). The species of Bathylagidae which have pedunculated eyes and are found in the Southwest Atlantic are M. bericoides and $D$. longirostris. The former is characterized by small melanophores on the intestine, whereas D. longirostris has two series of large melanophores set closely together, forming irregular rows below the lateral line (Kenaley \& Hamilton Jr. 2006).

Dolicholagus longirostris occurs between $39^{\circ} \mathrm{N}$ and $21^{\circ} \mathrm{S}$, in tropical and subtropical regions (Froese \& Pauly 2006). This species has been found previously in the eastern Atlantic (south of Portugal to Madeira Island), in the central and southwestern North Atlantic (Gulf of Mexico and Caribbean Sea), Suriname and French Guiana (South America), northwest Pacific (Japan), southwest Pacific (New Zealand), and the eastern Pacific (in the California Current region). According to published reports (Cohen 1964, 1990, Froese \& Pauly 2006, Kenaley \& Hamilton Jr. 2006), D. longirostris is widely distributed in tropical and temperate zones in the North Atlantic and in the North and South Pacific. This new finding contributes to future zoogeographical studies, because the known range of this species is extended to an equatorial zone (Southwest Atlantic Ocean).

\section{Acknowledgements}

This study was supported by the Executive Committee of the Interministerial Commission for Marine Resources (SECIRM), Brazilian Ministry of Environment (MMA), Sectoral Plan for Marine Resources of Brazil.

\section{References}

AHLSTROM, E.H., MOSER H.G. \& COHEN, D.M. 1984. Argentinoidei: Development and relationships. In Ontogeny and Systematics of Fishes (H.G. Moser, W.J. Richards, D.M. Cohen, M.P. Fahay, A.W. Kendall \& S.L. Richardson, eds.). American Society of Ichthyology and Herpetology, Spec. Pub. 1, p.155-169.
CAMARGO, M. \& ISAAC, V.J. 2003. Ictiofauna Estuarina. In Os manguezais da costa norte brasileira (M.E.B. Fernandes, ed.). Fundação Rio Bacanga, Maranhão, p.105-141.

CARPENTER, K.E. 2002. The living marine resources of the Western Central Atlantic. v. 2. Rome. FAO.

COHEN, D. M. 1964. Suborder Argentinoidea. In Fishes of the Western North Atlantic (H.B Bigelow; D.M. Cohen; M.M. Dick; R.H. Gibbs Jr.; M. Grey; J.E. Morrow Jr.; L.P. Schultz \& V. Walters, eds.). Memoir Sears Foundation for Marine Research, 1 Pt. 4, p.1-69.

COHEN, D.M. 1990. Bathylagidae. In Check-list of the fishes of the Eastern Tropical Atlantic (CLOFETA).(J.C. Quero; J.C. Hureau; C. Karrer; A. Post \& L. Saldanha, eds.). JNICT, Lisbon; SEI, Paris; and UNESCO, Paris. v. 1. p.239-240.

FIGUEIREDO, J.L., SANTOS A.P. dos, YAMAGUTI, N., BERNARDES, R.A. \& ROSSI-WONGTSCHOWSKI, C.L.D.B. 2002. Peixes da Zona Econômica Exclusiva da Região Sudeste-Sul do Brasil: Levantamento com Rede de Meia-Água. Editora da Universidade de São Paulo, São Paulo.

FROESE, R. \& PAULY, D. 2006. FishBase. World Wide Web electronic publication. www.fishbase.org/version (03/2006).

KENALEY, C.P. \& HAMILTON Jr., A.N. 2006. Bathylaginae: deep-sea smelts. In Early Stages of Atlantic Fishes: An Identification Guide for the Western Central North Atlantic (W.J. Richard, ed.). CRC Press, Boca Raton, Florida, v. 1, p.141-154.

MENEZES, N.A., BUCKUP, P.A., FIGUEIREDO, J.L. \& MOURA, R.L. 2003 Catálogo das espécies de peixes marinhos do Brasil. Museu de Zoologia, Universidade de São Paulo, São Paulo, 160p.

PAIVA, R.S. 2001. Parâmetros físicos, químicos, biomassa e produção primária do fitoplâncton na Plataforma Continental Amazônica. Tese de Doutorado, Universidade de São Paulo, São Paulo.

Title: First occurrence of Dolicholagus longirostris larvae (Maul 1948) (Osmeriformes, Bathylagidae) near the mouth of the Amazon River.

Authors: Campos, PN, Paiva, RS, Bonecker, ACT, Melo, NFAC, Palheta, GDA, Contente, CT, Ramos, CAR

Biota Neotropica, Vol.7 (number 1): 2007 http://www.biotaneotropica.org.br/v7n1/pt/abstract?shortcommunication+bn01007012007

Data Received 28/09/05 - Revised 20/09/06 Accepted 01/01/07

ISSN 1676-0603 